\title{
RELATIONSHIP OF PANCREATIC VOLUMES USING CT SCAN IN INDONESIAN ADULTS WITH AGE, SEX, AND BODY MASS INDEX
}

\author{
Abdul Mu'ti ${ }^{1,2}$, Swandari Paramita ${ }^{3}$ \\ ${ }^{1}$ Department of Biochemistry, Faculty of Medicine, Mulawarman University, Samarinda, ${ }^{2}$ Medical Program of \\ Radiology Specialist, Faculty of Medicine, Hasanuddin University, Makassar, ${ }^{3}$ Department of Community \\ Medicine, Faculty of Medicine, Mulawarman University, Samarinda, Indonesia
}

\section{ABSTRACT}

The volume of internal organs, including pancreas, show potential health problems. Several medical conditions are associated with the volume of the pancreas. The study aimed to determine the pancreatic volumes using a computed tomography (CT) scan in normal Indonesian adults and to determine whether the age, sex, and body mass index (BMI) influence the measurement of pancreatic volumes. The study was conducted by 119 people aged between 20-77 years old. Pancreatic volume measurement was performed using the summation of area technique. Statistical analyzes used independent $t$-test and Pearson correlation test. The study showed a significant difference of pancreatic volumes between normoweight and overweight individuals with $p=0.041$ ( $p<0.05)$. The results showed a significant difference of pancreatic volumes between male and female with $p=0.020$ ( $p<0.05)$. The results showed a significant correlation between pancreatic volumes and age $p=0.004$ ( $p<0.05)$. These findings suggest that the change in pancreas volume with age, sex, and BMI is comparable among different ethnicities, which is also in line with other studies.

Keywords: Pancreatic volume; CT scan; age; sex; body mass index

\begin{abstract}
ABSTRAK
Volume organ dalam, termasuk pankreas, menunjukkan potensi adanya masalah kesehatan. Beberapa kondisi medis berhubungan dengan volume pankreas. Penelitian ini bertujuan untuk menentukan volume pankreas menggunakan CT scan pada orang Indonesia dewasa dan untuk menentukan apakah usia, jenis kelamin, dan indeks massa tubuh (IMT) berhubungan dengan hasil pengukuran volume pankreas. Penelitian ini dilakukan terhadap 119 pasien berusia antara 20-77 tahun. Pengukuran volume pankreas dilakukan dengan teknik area sumasi. Analisis statistik menggunakan uji $t$ independen dan korelasi Pearson. Hasil penelitian menunjukkan perbedaan siginifikan volume pankreas antara individu yang normoweight dan overweight dengan $p=0,041$ ( $p<0,05)$. Hasil penelitian menunjukkan perbedaan signifikan volume pankreas antara laki-laki dan perempuan dengan $p=0,020(p<0,05)$. Hasil penelitian juga menunjukkan korelasi signifikan antara volume pankreas dan usia dengan p=0,004 ( $p<0,05$ ). Hasil penelitian ini menunjukkan bahwa perubahan volume pankreas yang dipengaruhi oleh usia, jenis kelamin, dan IMT dapat dibandingkan antar etnis yang berbeda, selaras dengan hasil penelitian lainnya.
\end{abstract}

Kata kunci: Volume pankreas; CT scan; usia; jenis kelamin; indeks massa tubuh

Correspondence: Swandari Paramita, Faculty of Medicine, Mulawarman University, J1 Kerayan Kampus Gunung Kelua, Samarinda, East Kalimantan. Phone/Fax +62541-748581. Email: swandariparamita@gmail.com

pISSN:2355-8393 • eISSN: 2599-056x • doi: 10.20473/fmi.v56i1.18448

- Fol Med Indones. 2020;56:31-35 • Received 10 Apr $2018 \bullet$ Accepted 18 Oct 2018

- Open access under CC-BY-NC-SA license • Available at https://e-journal.unair.ac.id/FMI/

\section{INTRODUCTION}

The volume of internal organs, including pancreas, show potential health problems. Several medical conditions are associated with the volume of the pancreas. Also, deviations from the normal ranges of the pancreas may indicate the presence of pathological problems. Normal anatomic ranges should be described in order to define pathological conditions. Many conditions are known to influence the volume of the pancreas. Meanwhile, the volumes of pancreas reference tables are only valid over a limited period of time and may vary among different populations (Caglar et al 2014).

Computed tomography (CT) scan is widely used for imaging of abdominal organs. The imaging of pancreas is mostly based on sectional imaging techniques - CT scan, MRI, and ultrasonography. As the non-invasive tool, CT scan is easily accepted by patients and has 
proven to be a very good diagnostic tool if performed by an expert. Lately, it has been used as an extension of the clinical examination, shortening the diagnostic time (Yokota et al 2012, Badea et al 2009).

CT scan parameters were very useful data for evaluating endocrine function. CT scan parameters for the assessment of endocrine function are in the volume of the pancreas. Volume parameters are postulated to represent the number of islets. On the other hand, density parameters were aimed to indicate the condition of blood flow in the pancreas. The study in Japan reported that glucose administration significantly increased blood flow of islet mass and islet during hyperglycemia received $85 \%$ more than during the basal condition. Thus, pancreas with good blood flow can be hypothesized to have a good function (Sakata et al 2011).

The study in Caucasians and Japanese adults reported the relationship between body mass index (BMI) and pancreas volume assessed by CT scan (Caglar et al 2012, Saisho et al 2007). However, since the majority of the study subjects were other ethnicities, the application of this measurement to Indonesian people may not be appropriate. Therefore, in this study, we aimed to explore the relationship between age, sex, BMI, and pancreas volume in Indonesian people.

\section{MATERIALS AND METHODS}

A total of 119 (52 men and 67 women) Indonesian adults aged 20 to 77 years who had undergone abdominal CT scan between July and September 2015 in Radiology Department of Dr. Wahidin Sudirohusodo Hospital and Hasanuddin University Hospital, Makassar. Cases were excluded if they had any abdominal condition potentially affecting pancreas morphology (e.g., pancreatitis and peritonitis). The abdominal CT scan findings were evaluated by an independent radiologist to confirm the absence of pancreas pathology. Since the existence of diabetes affects pancreas volume, patients with diabetes were also excluded from the study. In the present study, we examined health-check examinees that had not been diagnosed with overt diabetes or received any medication in relation to glucose intolerance.

CT images were acquired with a standard clinical abdominal CT protocol utilizing MDCT General Electric (GE) LightSpeed VCT® 64 Slice in $1.25 \mathrm{~mm}$ thick section, and MDCT Dual Source (DSCT) Siemens Definition Flash ${ }^{\mathrm{TM}} 128$ Slice in $0.6 \mathrm{~mm}$ thick section. All images were transferred to a standard workstation
(GE Advantage Workstation 4.2 and Syngo® via Workstation-Siemens Healthcare Global). The pancreas was outlined by hand in each CT image as previously described and the pancreas volume was computed by summing the product of pancreas area $(\mathrm{cm} 2)$ of each image and the CT section thickness. This study was approved by the ethics committee of Faculty of Medicine, Hasanuddin University, Makassar, Indonesia.

\section{RESULTS}

The mean pancreas volume was $65.7 \pm 18.3 \mathrm{~cm} 3$. Table 1 and Table 2 shows a significant relationship between BMI and pancreas volume $(\mathrm{p}=0.014)$, and between sex and pancreas volume $(\mathrm{p}=0.02)$. Table 3 shows a significant correlation between age and pancreas volume $(r=-0.264$ and $p=0.004)$. The mean age of the subjects was $49.7 \pm 13.1$ years.

Table 1. The result of the mean of pancreatic volume on body mass index

\begin{tabular}{cccc}
\hline Body Mass Index & $\mathrm{N}$ & Pancreatic Volume Mean & $\mathrm{SD}$ \\
\hline Normoweight & 85 & 63.58 & 17.10 \\
Overweight & 34 & 71.17 & 20.35 \\
\hline Note: t-test; $\mathrm{p}=0.041(\mathrm{p}<0.05)$ & &
\end{tabular}

Table 2. The result of the mean of pancreatic volume on sex

\begin{tabular}{cccc}
\hline Sex & $\mathrm{N}$ & Pancreatic Volume Mean & SD \\
\hline Male & 52 & 70.16 & 18.92 \\
Female & 67 & 62.33 & 17.22 \\
\hline \multicolumn{7}{l}{ Note: $t$-test; $\mathrm{p}=0.020(\mathrm{p}<0.05)$}
\end{tabular}

\section{DISCUSSION}

The mean pancreas volume in this study was $65.7 \pm$ $18.3 \mathrm{~cm} 3$. This result is smaller to those in the literature mentioned below. Previous reports have demonstrated differences in the pancreatic volume in CT, MRI, and autopsy. The study in Turkey found that the mean pancreas volume was $88.6 \mathrm{~cm} 3$ in the autopsy. The study in Germany reported that pancreas volume was $86.5 \mathrm{~cm} 3$ in the autopsy. The study in the United States reported an average pancreas volume of $87.4 \mathrm{~cm} 3$ in male autopsy (Caglar et al 2014). The study in Japan reported an average pancreas volume in CT of $71.5 \mathrm{~cm} 3$ (Saisho et al 2007). The study in Turkey found that the mean pancreas volume was $67.71 \mathrm{~cm} 3$ in CT. The study reported that the mean pancreas volume in CT was 76 $\mathrm{cm} 3$ in Sweden. 


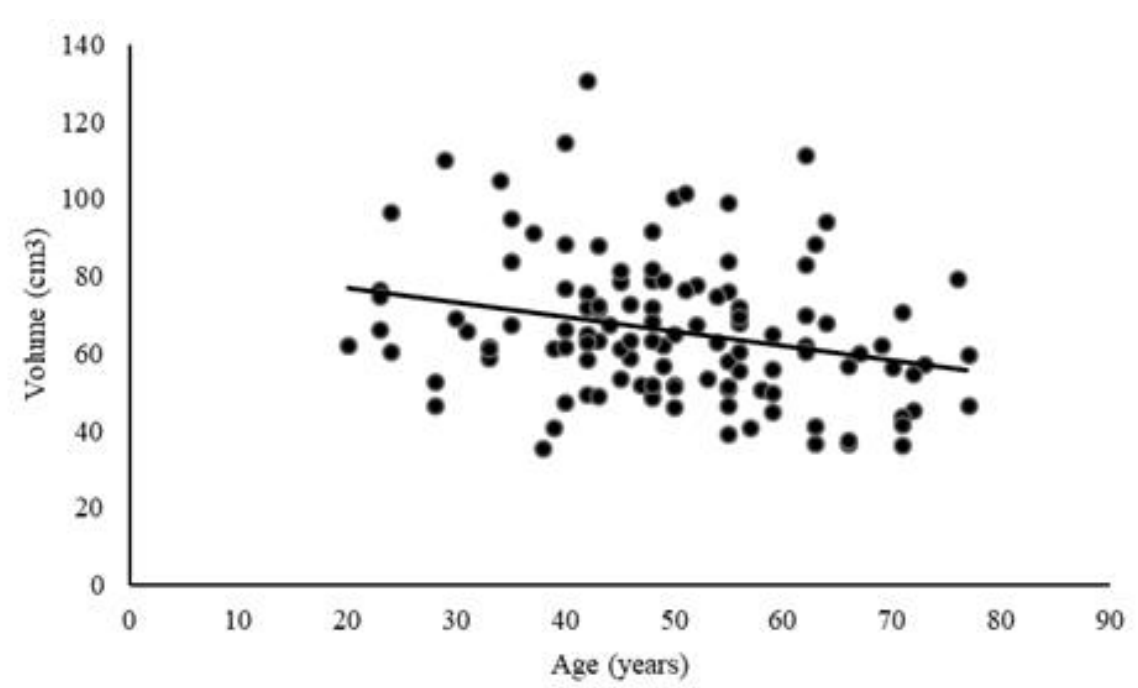

Fig. 1. Correlation of pancreatic volume on age. Note: $20-77$ years; $r=-0.264 ; p=0.004(p<0.05)$.

The study in the United Kingdom reported an average pancreas volume in CT of $101 \mathrm{~cm} 3$ and study in Serbia reported an average pancreas volume of $79 \mathrm{~cm} 3$ in CT (Caglar et al 2012). The study in the United States reported an average pancreas volume in MRI of 72.7 cm3 (Szczepaniak et al 2013). Differences in the literature on pancreas volume may be due to differences in the number, mean age, and sex of individuals enrolled in the study and regional differences between populations.

Our study found that pancreas volumes are positively correlated with age, sex, and body mass index (BMI). Pancreas volume is altered by normal events such as aging or weight gain. For example, pancreas volume increases in a linear fashion from birth to age 20; decreases following age 60 and pancreas shows a linear correlation with body weight (Burute et al 2014). There is a relationship between BMI and pancreas volume assessed by CT. Since it has been shown that pancreas volume linearly increases in childhood and reaches the plateau at 20 years, then it starts to decline after 60 years of age, this is the age range to minimize the agerelated effect on pancreas volume (Kou et al 2014). The pancreas continues to grow until approximately 20 years of age. Thus, only individuals older than 20 years of age were included in this study (Caglar et al 2014). Until about 20 years of age, an anatomical increase in the size of the organ was established, while a later agedependent involution was confirmed (Caglar et al 2012). Pancreatic volume in healthy people declines in size with age (Szczepaniak et al 2013). For example, anatomical studies report decreased pancreas volume with aging in humans and histological studies report atrophy, fibrosis, and fatty infiltration of the pancreas in the aging population. Pancreas volume increases in a linear fashion from birth to age 20 years and thereafter reaches a plateau, a finding consistent with available anatomical studies (Saisho et al 2007).

Our study reported an average pancreas volume in CT of $63.3 \mathrm{~cm} 3$ in female and $70.1 \mathrm{~cm} 3$ in the male. This study showed significant differences in pancreatic volumes between male and female with $\mathrm{p}=0.020$ $(p<0.05)$. Our results are smaller to those in the literature mentioned below. The study in Germany reported an average pancreas volume in CT of $64.4 \mathrm{~cm} 3$ in female and $87.4 \mathrm{~cm} 3$ in the male. The study in Turkey reported mean pancreas volume is greater in males than it is in females by $11.2 \%$ (Caglar et al 2012). The study in Japan reported an average pancreas volume in CT of $63.0 \mathrm{~cm} 3$ in female and $85.2 \mathrm{~cm} 3$ in male (Saisho et al 2007). All the literature report that the pancreas volumes are greater in males than females, which is consistent with the anatomical studies.

We found a significant correlation between pancreas volume and BMI. There was a significant relationship between BMI and pancreas volume $(p=0.014)$. Organ size is usually associated with height and weight. The study in Japan reported effects of body mass index (BMI) on pancreas volume (Saisho et al 2007). The study in Turkey also reported the correlation between pancreas volume and BMI. The presence of a significant relationship between BMI and pancreas volume suggests an effect of obesity on the pancreatic volume. The fact that pancreas volume is greater in obese persons may be due to an increase in the pancreatic fat 
rather than an increase in the pancreatic parenchyma. This is also supported by the study who reported that the degree of pancreatic lipomatosis was significantly associated with age and overweight. This condition is more compatible with the prevalence of diabetes in obese people (Caglar et al 2012).

Obesity has become one of the major health issues of the 21st century, affecting both developed and developing nations. It is estimated that 1.5 billion of the global population will be overweight or obese by the year 2030. It is now generally accepted that elevated levels of body adiposity, amplify the risks of developing chronic, life-threatening diseases. There are many methods for estimating relative body adiposity and BMI is the most frequently used. Obesity is associated with many medical conditions, including diabetes mellitus (Thomas et al 2012, Schindera et al 2007).

The importance of both visceral and ectopic fat as an endocrine organ that secretes multiple adipokines has been appreciated. Under conditions of oxidative stress, this cytokine milieu has been demonstrated to produce a local inflammatory response and organ dysfunction. This has been most studied in the liver, where fat deposition in hepatocytes has been shown to lead to nonalcoholic fatty liver disease and nonalcoholic steatohepatitis (Burute et al 2014). Abnormal fat deposition of the pancreas has many harmful effects, including oxidative stress, inflammation, and apoptosis of the islets. According to some studies of pathological observations in the human pancreas, fat deposition appears mainly in interlobular septa rather than within cells. As the b-cell was suggested to be differentiated from the area near the pancreatic duct, it is possible that b-cell replication is decreased by the fatty infiltration that causes the decline in insulin secretion (Yokota et al 2012). Recent advances in computed tomography (CT) permit accurate noninvasive measurement of organ volume. Moreover, this approach permits the measurement of the proportion of the organ occupied by fat. It believes that pancreatic fat may have deleterious effects on pancreatic b-cells (Sepe et al 2011).

\section{CONCLUSION}

In conclusion, we demonstrated a positive correlation between BMI and pancreas volume in Indonesian adults, and this relationship is similar to that study in Caucasians and Japanese adults. These findings suggest that the change in pancreas volume with obesity is comparable among different ethnicities, which is also in line with other studies. This information will be useful to estimate the impact of obesity on pancreas volume in
Indonesia adults and for comparison among different ethnicities.

\section{ACKNOWLEDGMENT}

Acknowledgment for Bachtiar Murtala, Muhammad Ilyas and Nurlaily Idris from Department of Radiology, Faculty of Medicine, Hasanuddin University, Makassar for their scientific guidance for this research.

\section{REFERENCES}

Badea R, Seicean A, Diaconu B, Stan-Iuga R, Sparchez Z, Tantau M, Socaciu M (2009). Contrast-enhanced ultrasound of the pancreas - a method beyond its potential or a new diagnostic standard?. JGLD 18, 237-242

Burute N, Nisenbaum R, Jenkins DJ, Mirrahimi A, Anthwal S, Colak E, Kirpilani A (2014). Pancreas volume measurement in patients with type 2 diabetes using magnetic resonance imaging-based planimetry. Pancreatology 14, 268-274

Caglar V, Kumral B, Uygur R, Alkoc OA, Ozen OA, Demirel H (2014). Study of volume, weight and size of normal pancreas, spleen and kidney in adults autopsies. FMAR 2, 63-69

Caglar V, Songur A, Yagmurca M, Acar M, Toktas M, Gunul Y (2012). Age-related volumetric changes in pancreas: a stereological study on computed tomography. Surg Radiol Anat 34, 935-941

Kou K, Saisho Y, Jinzaki M, Itoh H (2014). Relationship between body mass index and pancreas volume in Japanese Adults. JPO 15, 626-627

Saisho Y, Butler AE, Meier JJ, Monchamp T, AllenAuerbach M, Rizza RA, Butler PC (2007). Pancreas Volumes in Humans from Birth to Age One Hundred Taking Into Account Sex, Obesity, and Presence of Type-2 Diabetes. Clin Anat 20, 933-942

Sakata N, Egawa S, Rikiyama T, Yoshimatsu G, Masuda K, Ohtsuka H, Ottomo S, Nakagawa K, Hayashi H, Morikawa T, Onogawa T, Yamamoto K, Yoshida H, Akada M, Motoi F, Naitoh T, Katayose Y, Unno M (2011). Computed tomography reflected endocrine function of the pancreas. J Gastrointest Surg $15,525-532$

Schindera ST, Nelson RC, Lee ER, DeLong DM, Ngyen G, Toncheva G, Yoshizumi TT (2007). Abdominal Multislice CT for Obese Patients: Effect on Image Quality and Radiation Dose in a Phantom Study. Acad Radiol 14, 486-494

Sepe PS, Ohri A, Sanaka S, Berzin TM, Sekhon S, Bennett G, Mehta G, Chuttani R, Kane R, Pleskow D, Sawhney MS (2011). A prospective evaluation of fatty 
pancreas by using EUS. Gastrointest Endosc 73, 98793

Szczepaniak EW, Malliaras K, Nelson MD, Szczepaniak LS (2013). Measurement of Pancreatic Volume by Abdominal MRI: A Validation Study. PLOS One 8, e55991
Thomas EL, Frost G, Taylor-Robinson SD, Bell JD. (2012). Excess body fat in obese and normal-weight subjects. Nutr Res Rev, 1-12

Yokota K, Fukushima M, Takahashi Y, Igaki N, Seino S (2012). Insulin secretion and computed tomography values of the pancreas in the early stage of the development of diabetes. J Diabetes Investig 3, 371376 